\title{
PENERAPAN INSPIRASI FAUNA DAN FLORA SUMATERA TERHADAP PERANCANGAN MOTIF TEKSTIL KONTEMPORER
}

\author{
Marini Yunita Tanzil \\ (Email: marini.yunita@ciputra.ac.id) \\ Visual Communication Design \\ Alur Studi Fashion Design and Business \\ Fakultas Industri Kreatif \\ Universitas Ciputra \\ UC Town, Citraland Surabaya, 60219, Indonesia.
}

\begin{abstract}
ABSTRAK
Sumber kekayaan alam hayati di Indonesia sangat kaya akan ragam dan memiliki keunikan tak ternilai harganya. Menonjolkan kekayaan alam Indonesia melalui motif tekstil adalah tujuan dari penelitian ini, terutama fauna dan flora endemik Pulau Sumatra. Penelitian ini dilakukan melalui metode deskriptif kualitatif berupa eksplorasi dan studi literatur pada tahap pertama dan implementasi desain pada tahap kedua. Eksplorasi tahap pertama adalah pada flora dan fauna Sumatra, unsur motif batik, motif tekstil kontemporer, komposisi, dan tren warna. Hasil dari penelitian akan ditampilkan di tahap kedua melalui implementasi perancangan motif tekstil kontemporer yang dapat diaplikasikan kepada produk fashion. Diharapkan penelitian ini dapat menjadi pedoman dan inspirasi bagi desainer tekstil dan fashion dalam merancang motif tekstil kontemporer dengan inspirasi alam dan budaya Indonesia.
\end{abstract}

Kata Kunci: desain tekstil; fashion; motif; pattern; tekstil

\begin{abstract}
Indonesian has a very rich, unique, and priceless biodiversity and natural resources. Featuring this national treasure is the aim of this research, especially the fauna and flora endemic to Sumatra Island. This research is executed through descriptive qualitative method by exploration and literature study for the first stage and design implementation for the second stage. The first stage contains exploration on Sumatran flora and fauna, batik motifs, contemporary textile design, color composition and trend. The finding of the research is presented at the second stage through contemporary textile motif as the design implementation that can be applied to fashion products. Expectantly, this research can provide guideline and inspiration for textile and fashion designers in developing contemporary textile motifs that take inspirations from the nature and culture of Indonesia.
\end{abstract}

Keywords: fashion; motif; pattern; textile; textile design

\section{PENDAHULUAN}

Indonesia adalah negara yang memiliki sumber alam hayati yaitu fauna dan flora liar yang meliputi mamalia, reptil, amfibi, dan burung dengan tingkat keanekaragaman tertinggi ketiga di dunia. Kawasan hutan di Indonesia yang memiliki luas sebesar 95.271,9 juta ha merupakan salah satu kontributor penting dalam menjaga kestabilan iklim dunia serta rumah bagi berbagai fauna dan flora endemik. Kawasan hutan terluas terletak di pulau- 
pulau terbesar seperti Pulau Sumatra dengan total luas hutan sebesar 21.892.416 ha, Pulau Kalimantan dengan total luas hutan sebesar 36.745.123 ha, Pulau Sulawesi dengan total luas hutan sebesar 13.512.845 ha, dan Pulau Irian dengan total luas hutan sebesar 40.100.636 ha (Kementerian Lingkungan Hidup dan Kehutanan, 2017).

Kendati luas kawasan dan biodiversity yang teramat kaya, hutan Indonesia terus mengalami kerusakan dan deforestasi akibat eksploitasi hutan yang dilakukan bagi pemukiman, perkebunan, industri, serta kepentingan ekonomis dan komersial lainnya (WWF Indonesia, n.d.). Berdasarkan data statistik dari Kementrian Lingkungan Hidup dan Kehutanan (2017), setidaknya 1,1 juta hektar atau 2\% dari hutan Indonesia habis ditebang setiap tahunnya. Seiring dengan penyusutan area kawasan hutan, populasi fauna dan flora yang kelangsungan hidupnya bergantung kepada hutan pun menurun. Harimau Sumatra menduduki peringkat pertama di dalam daftar 25 satwa yang terancam punah di Indonesia, dengan jumlah 72 ekor, berikut Gajah Sumatra di urutan kedua dengan jumlah 75 ekor, dan Badak Sumatra di urutan ketiga dengan jumlah 12 ekor (Kementerian Lingkungan Hidup dan Kehutanan, 2017).

Atas dasar data tersebut, penulis hendak merancang motif tekstil yang terinspirasi dari fauna dan flora endemik dari Pulau Sumatra, seperti yang terdapat pada motif batik pesisir Indramayu yang kerap menggunakan unsur flora dan fauna di sekitarnya (Elliott, 2004). Motif ini akan menggambarkan fauna dan flora yang disusun secara ritmis dan dinamis, serta menggunakan gaya desain dan palet warna kontemporer. Tujuan menggunakan fauna dan flora dari Sumatra adalah untuk meningkatkan kesadaran dan perhatian masyarakat Indonesia terhadap isu yang dihadapi alam Indonesia. Terutama dari Pulau Sumatra yang menempati tiga peringkat pertama dari daftar fauna yang terancam kepunahannya (Kementerian Lingkungan Hidup dan Kehutanan, 2017). Hasil dari perancangan motif dapat direpetisi tanpa batas dan diaplikasikan pada tekstil melalui teknik digital printing. Tekstil dengan pattern fauna dan flora Sumatra ini dapat difungsikan menjadi berbagai macam produk fashion, seperti busana dan aksesoris yang dapat dikenakan oleh masyarakat luas.

\section{METODE PENELITIAN}

Penelitian ini akan menggunakan metode deskriptif kualitatif dengan tujuan untuk memahami dan mengeksplorasi subjek serta teori yang akan digunakan untuk 
perancangan motif tekstil (Kawamura, 2011). Demikian proses penelitian tahap pertama mencakup eksplorasi dan studi literatur secara online dan offline mengenai fauna dan flora di Pulau Sumatra, motif tekstil kontemporer, teori perancangan motif tekstil repetisi, unsur motif batik, dan komposisi serta tren warna tahun 2017/2018. Tahap kedua mencakup hasil perancangan motif beserta aplikasi pada produk fashion berdasarkan hasil eksplorasi dan studi literatur.

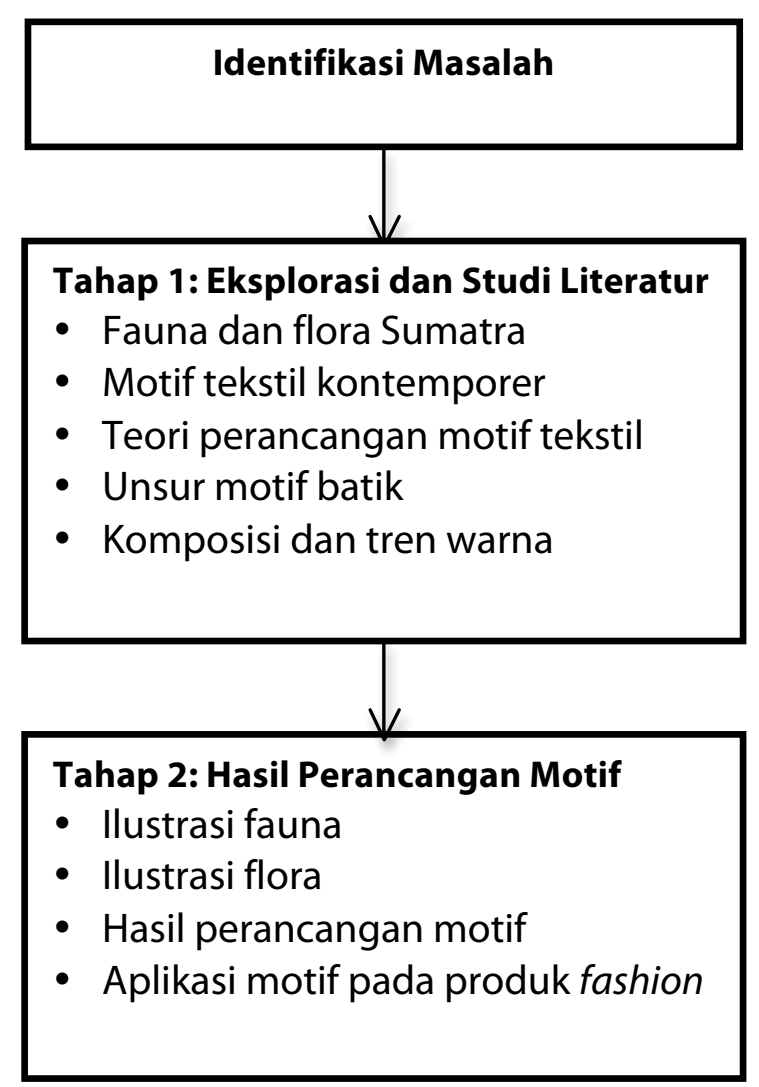

\section{TAHAP PERTAMA: EKSPLORASI DAN STUDI LITERATUR FAUNA DAN FLORA SUMATRA}

Ekosistem di setiap area yang berbeda-beda baik dari segi iklim, air, dan tanah memberikan keanekaragaman hayati yang unik dan khas di area tersebut.

Berikut adalah fauna endemik Pulau Sumatra yang akan digunakan sebagai elemen dalam perancangan motif:

\section{Harimau Sumatra}

Harimau Sumatra (Panthera tigris sondaica) adalah predator di tingkat teratas dalam rantai makanan di area habitatnya dan merupakan satu-satunya subspesies harimau yang tersisa 
dan hanya dapat ditemukan di Pulau Sumatra. Dua subspesies harimau lain, yakni Harimau Jawa dan Harimau Bali telah dinyatakan punah pada tahun 1937 untuk Harimau Bali dan 1980-an untuk Harimau Jawa (Putri, 2018).

Menurut Direktur Jenderal Konservasi Sumber Daya Alam dan Ekosistem (KSDAE) Kementerian Lingkungan Hidup dan Kehutanan, Wiratno (CNN, 2017), Harimau Sumatera merupakan simbol kelestarian ekosistem dan salah satu biodiversitas Indonesia yang paling berharga dan membanggakan.

Namun seperti yang telah tersebut di bab pendahuluan, status keberadaan Harimau Sumatra sedang berada di titik yang berbahaya akibat dari deforestasi, perburuan dan perdagangan yang tidak bertanggung jawab (Putri, 2018).

Ciri-ciri fisik khas yang akan diadaptasi sebagai referensi untuk ilustrasi Harimau Sumatra adalah motif belang yang unik di seluruh permukaan kulitnya, motif belang di keningnya menyerupai karakter Cina "wang" yang memiliki arti raja, kaki belakang yang lebih panjang dari kaki depannya, dan ekor yang memiliki kirasan panjang satu meter (WWF Indonesia, 2017).

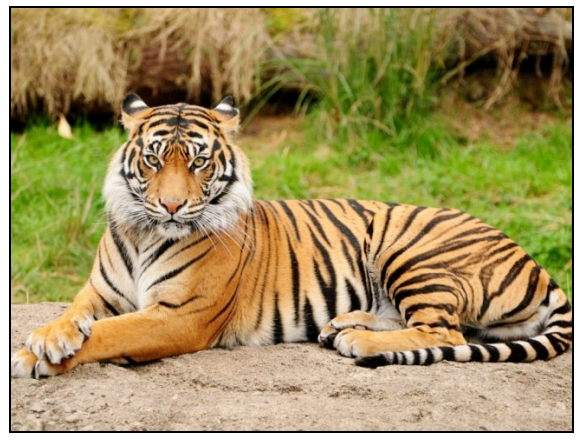

Gambar 1. Harimau Sumatra Sumber: www.pedomanbengkulu.com

\section{Badak Sumatra}

Jumlah jenis spesies badak yang tersisa di dunia hanyalah 5 pesies, dengan 2 di antaranya adalah Badak Sumatra (Dicerorhinus sumatrensis) yang hanya tersisa 12 ekor dan Badak Jawa dengan sisa 11 ekor (Kementerian Lingkungan Hidup dan Kehutanan, 2017).

Menurut Koordinator Program Proyek Ujung Kulon WWF Indonesia, Yuyun Kurniawan (Tempo, 2016), kondisi perkembangan populasi Badak Sumatra lebih kritis dibandingkan dengan Badak Jawa yang dikarenakan keberadaan Badak Sumatra yang tersebar dalam jumlah kecil. Melihat jumlah populasi Badak Sumatra yang sangat rendah, apabila upaya proaktif untuk meningkatkan pertumbuhan populasi tidak dilakukan, maka dalam waktu 
dekat spesies badak ini dapat punah.

Berdasarkan hasil observasi online, fitur fisik dari Badak Sumatra yang paling menonjol adalah cula di kepalanya yang berjumlah dua, dengan cula yang di depan lebih tinggi dan lebih besar dari cula kedua yang terletak di atas matanya.

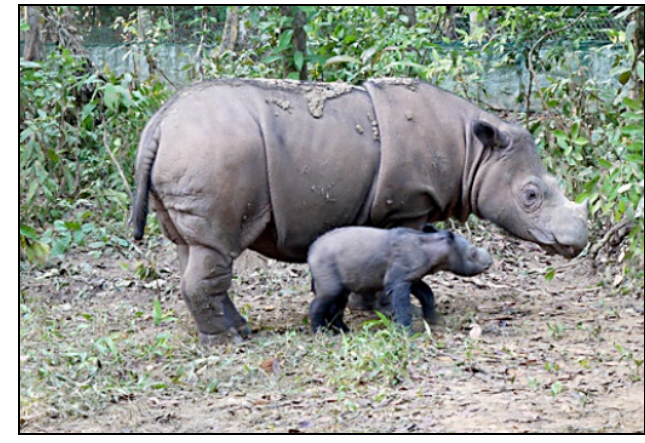

Gambar 2. Induk dan bayu Badak Sumatra

Sumber: International Rhino Foundation

\section{Orangutan Sumatra}

Orangutan Sumatra (Pongo abelii) adalah jenis orangutan yang paling terancam eksistensinya oleh karena laju penyusutan habitat akibat deforestasi dan perburuan liar. Namun dibandingkan dengan perkiraan populasi yang tercatat 6.667 ekor pada tahun 2004, populasi Orangutan Sumatra pada tahun 2017 diperkirakan mencapai 14.470 ekor dan akan sedang terus diupayakan pelestariannya oleh Kementerian Lingkungan Hidup dan Kehutanan yang bekerja sama dengan Forum Orangutan Indonesia, beserta para aktivis konservasi orangutan dan Forum Orangutan Regional (Ratya, 2017).

Fitur fisik Orangutan Sumatra yang khas adalah kantung pipi dan bentuk dagu panjang yang didapati pada orangutan jantan dewasa. Orangutan Sumatra memiliki tingkat intelejensi tinggi yang ditunjukkan melalui penggunaan ranting sebagai alat untuk mengkonsumsi buah-buahan. Primata ini menghabiskan sebagian besar waktunya bergelantungan dari pohon ke pohon untuk menghindari predator utamanya, yaitu Harimau Sumatra (WWF Indonesia, n.d.).

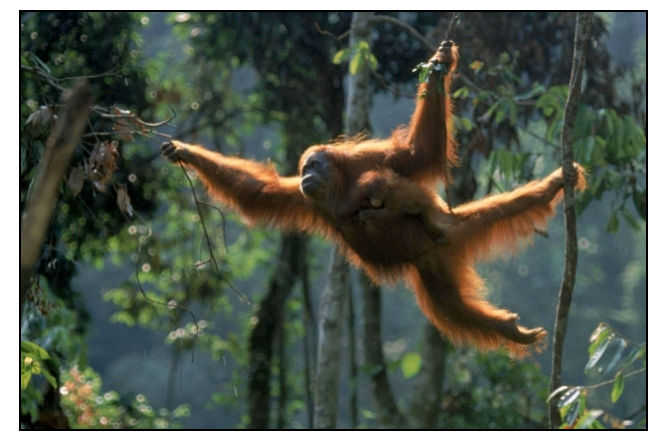




\section{Burung Malayan Banded Pitta}

Malayan banded pitta (Hydrornis irena) adalah spesies burung yang dapat ditemui di Pulau Sumatra, Malaysia, dan Thailand. Seperti keluarga burung Pittidae lainnya, Malayan banded pitta terancam jumlah populasinya dikarenakan oleh deforestasi dan perdagangan burung ekstotis ilegal yang dapat dengan mudah ditemukan di pasar burung di Indonesia (Ramos, 2016).

Spesies burung ini memiliki motif dan warna bulu yang sangat indah dan menarik, serta suara yang merdu, sehingga menjadi sasaran pemburu liar untuk menangkap dan memperjualbelikannya.



Gambar 4. Malayan Banded Pitta

Sumber: www.datazone.birdlife.org

Selain fauna, adapun flora endemik Pulau Sumatra yang akan digunakan sebagai elemen dalam perancangan motif:

\section{Bunga Suweg Raksasa}

Suweg raksasa (Amorphophallus titanum) merupakan jenis bunga bangkai endemik Pulau Sumatra yang tingginya dapat mencapai 3,17 meter. Bunga Suweg ini mengalami dua fase yang muncul bergantian sepanjang siklus hidupnya, yaitu fase generatif dan fase vegetatif dengan batangnya akan muncul dan mahkota daunnya akan merekah penuh (Fakta Unik, 2017).

WWF (n.d) menyatakan bahwa populasi Bunga Suweg raksasa tergolong dalam status terancam oleh akibat dari berkurangnya lahan hutan dan warga setempat yang memotong bunga ini karena terganggu oleh bau busuknya. 


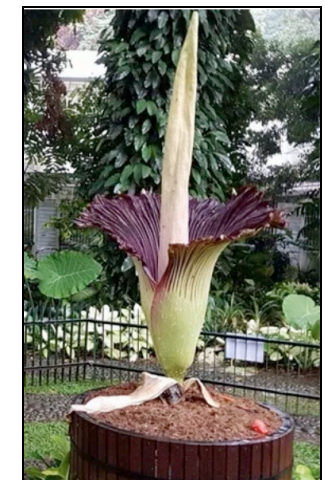

Gambar 5. Suweg Raksasa

Sumber: www.nuswantaranews.com

\section{Rafflesia Arnoldii}

Bunga bangkai endemik Pulau Sumatra lainnya adalah Rafflesia arnoldii yang dianggap sebagai salah satu bunga nasional di Indonesia. Bunga ini merupakan tanaman parasit yang tidak memiliki batang, daun, maupun akar, dan hidup menumpang pada tanaman inangnya. Diameter bunga Rafflesia arnoldii dapat mencapai 1 meter dengan bentuk menyerupai pot yang dikelilingi oleh lima kelopak berwarna merah serta bintik-bintik berwarna putih (Pikiran Rakyat, 2018).

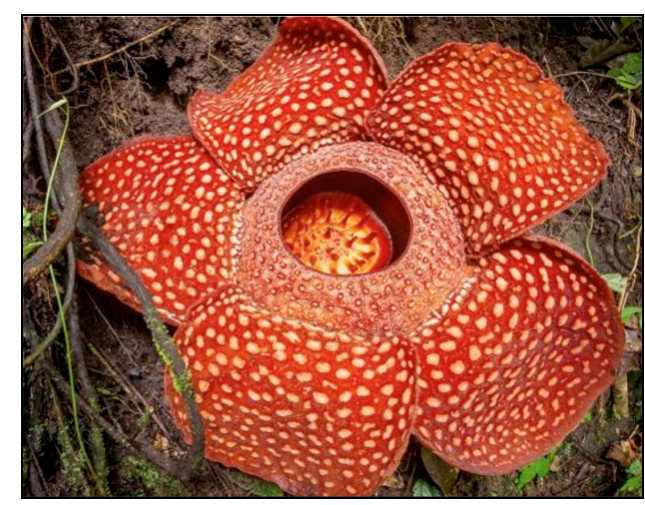

Gambar 6. Rafflesia arnoldii Sumber: www.worldatlas.com

\section{Pinang Merah}

Tanaman pinang atau palem merah (Cyrtostachys renda) merupakan flora maskot Propinsi Jambi dan kerap digunakan sebagai tanaman hias. Keunikan dari tumbuhan ini dibandingkan dengan tumbuhan palem lainnya adalah batang, pelepah dan bijinya yang berwarna merah cerah membuatnya sering pula disebut pinang lipstik (Gerhat, 2016). 


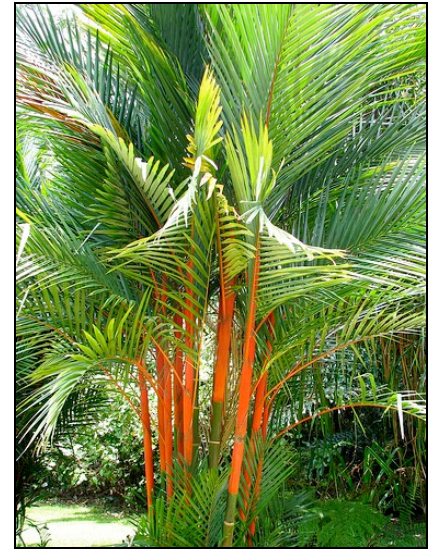

Gambar 7. Pinang Merah Sumber: www.himakova.Ik.ipb.ac.id

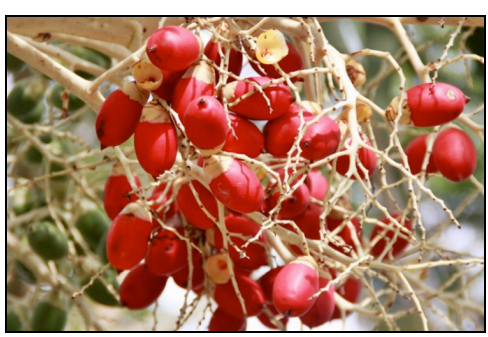

Gambar 8. Biji Pinang Merah Sumber: www.himakova.Ik.ipb.ac.id

\section{MOTIF TEKSTIL KONTEMPORER}

Seni kontemporer memiliki arti seni pada saat ini, dengan karya seni diciptakan oleh seniman yang masih hidup dan berkarya, dan merupakan ekspresi atau refleksi dari isu-isu terkini. Oleh karena itu, seni kontemporer sendiri tidak memiliki periode waktu tertentu, karena selalu bergerak progresif seiring dengan perkembangan zaman. Karya-karya seni kontemporer seringkali merupakan karya eksperimental dengan pilihan medium yang tidak terbatas untuk merefleksikan isu-isu sosial, budaya, ekonomi, politik terkini (The Artist Editorial, 2017).

Menurut O'Meara (2015), saat ini desain tekstil dikuasai oleh media digital dengan teknologi-teknologi baru yang dapat memberikan hasil yang lebih bervariasi dan tingkat presisi yang tinggi. Namun seiring makin maraknya penggunaan alat dan media digital dalam proses dan pengerjaan desain, apresiasi terhadap desain dan konstruksi tekstil yang diciptakan menggunakan keterampilan tradisional dan pekerjaan tangan manual. 


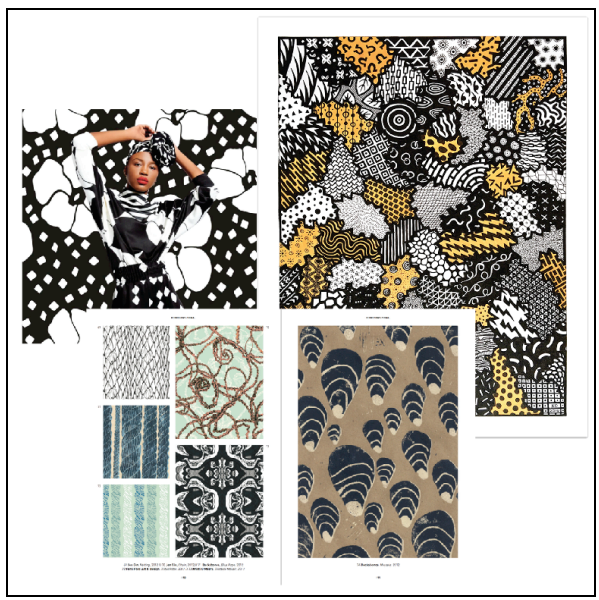

Gambar 9. Desain Motif Tekstil Kontemporer Sumber: www.thepatternbase.com

Oleh karena itu, dapat disimpulkan bahwa desain motif kontemporer saat ini kerap menggunakan unsur keterampilan tangan untuk menciptakan ilustrasi yang diolah secara digital untuk menghasilkan desain motif berkesan manual namun tetap terlihat up-to-date.

\section{TEORI PERANCANGAN MOTIF TEKSTIL}

Motif telah digunakan sebagai unsur dekoratif pada tekstil sejak berabad-abad yang lalu hingga saat ini dengan adaptasi ukuran, bentuk, komposisi dan warna pada setiap perubahan tren. Teori-teori seperti prinsip geometri dan bentuk, ritme, keseimbangan, harmoni, dan ketepatan simetri digunakan ketika menciptakan motif (Justema, 1976). Motif sendiri adalah komposisi dari pattern. Pattern merupakan suatu desain yang terdiri dari satu atau lebih motif yang digandakan dan disusun dalam interval yang reguler di atas suatu permukaan, dan biasa disebut pattern repetisi / repeat pattern (Justema, 1976).

Untuk gambar flora, ritme yang seimbang dapat diciptakan dengan merotasi dan merefleksi motif hingga mencapai efek dan struktur yang luwes dan tidak kaku. Distribusi area negatif yang seimbang sangat penting untuk dalam membuat desain motif (Bowles and Isaac, 2009).

Menurut Clarke (2011), pattern memiliki pengaruh yang kuat untuk menarik perhatian dan merangsang emosi dari orang yang melihatnya dan dapat menjadi media untuk merefleksikan atmosfer dan keadaan pada suatu masa tertentu. Desainer fashion Marie Katrantzou menyatakan bahwa saat ini desainer dan konsumen dapat menciptakan dan mengkomunikasikan estetika individu melalui pattern (Doe, 2015). 


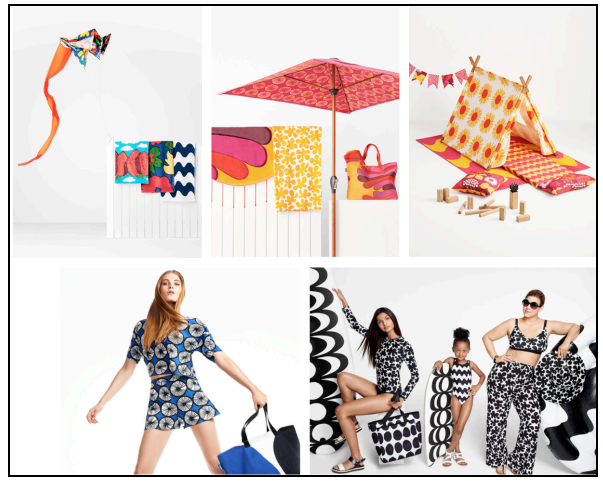

Gambar 10. Motif Marimekko Untuk Target Sumber: www.us.marimekko.com

Dengan berkembangnya teknologi digital, limitasi dalam membuat pattern dapat diabaikan. Mencetak pattern di atas tekstil dalam jumlah seminimalis mungkin dapat dilakukan dengan metode digital printing dengan jumlah warna dan ukuran motif yang tidak terikat oleh limitasi seperti halnya pada screen printing (Clarke, 2011).

\section{UNSUR MOTIF BATIK}

Perancangan ini juga terinspirasi dari motif batik yang merupakan warisan budaya Indonesia untuk menambahkan unsur kebudayaan lokal ke dalam desain motif tekstil ini. Motif batik yang menjadi inspirasi utama adalah batik Indramayu yang terdiri dari pola-pola kecil yang terdiri dari sulur, pohon, dan bunga yang disusun membentuk pola yang harmonis (Kartasasmita, 2012). Motif batik Indramayu modern memiliki banyak pengaruh dari motif kaligrafi dan gambar dari negara Arab dan Cina dengan gaya desain yang cenderung bebas tanpa banyak ikatan tradisi atau makna yang simbolis, melainkan hanya sebagai wujud ekspresi dan apresiasi artistik terhadap keindahan sumber alam sekitar (Infobatik, n.d.)

Motif batik Indramayu kerap menggambarkan flora dan fauna sekitar yang telah distilasi menggunakan bentuk-bentuk lengkung, garis yang meruncing, dan titik-titik sebagai ornamen pengisi yang disebut 'cecek-cecek' (Elliott, 2004). 


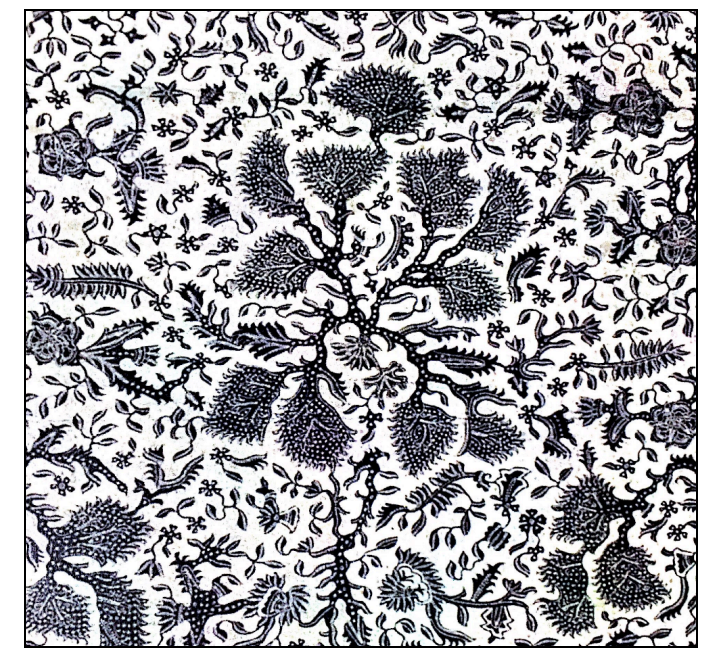

Gambar 11. Batik Indramayu tahun 1970 Sumber: Dunia Batik Seorang Jultin, p.184, 2012

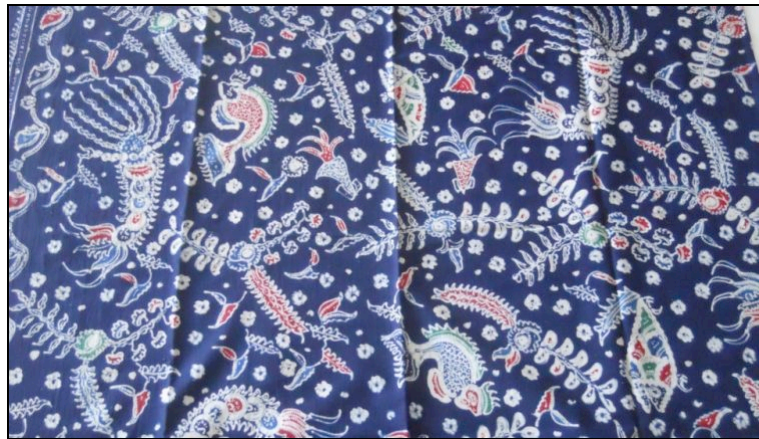

Gambar 12. Batik Indramayu Motif Iwak Etong Sumber: www.infobatik.id

Motif batik terdiri dari ornamen pokok, ornamen pelengkap, dan ornamen pengisi atau sering disebut 'isen-isen'. Unsur-unsur yang dipilih adalah fauna dan flora endemik Pulau Sumatra sebagai ornamen pokok, ornamen tumbuh-tumbuhan seperti daun dan sulur sebagai ornamen pelengkap, kemudain cecek-cecek (titik-titik), cecek pitu (titik tujuh), cecek sawut (garis bertitik), parang rusak, dan herangan (pecah berserakan) sebagai pengisi ornamen utama dan ornamen pelengkap (Roojen, 1993).

\section{KOMPOSISI DAN TREN WARNA}

Warna memberi pengaruh yang sangat besar terhadap desain tekstil. Hubungan antara pattern dan warna sangat kuat karena keduanya menciptakan harmoni yang memberi pengaruh langsung terhadap atmosfer dan emosi di dalam suatu desain. Oleh karena itu, desainer harus memiliki pengetahuan dan pengalaman dalam memilih, mengkombinasikan, dan mencocokkan warna yang sesuai dengan teori dan tren warna (Clarke, 2011). 
Perpaduan warna yang akan digunakan di dalam desain motif ini adalah kontras antara warna sejuk dan warna hangat dengan menggunakan warna biru, hijau, dan biru-hijau sebagai sejuk, serta warna merah, merah-oranye dan merah muda oranye sebagai warna hangat. Kontras warna sejuk dan hangat ini digunakan untuk memberi kesan ekspresif dan dampak visual yang tinggi kepada motif (Clarke, 2011).

Palet warna yang dipilih terinspirasi dari lima warna tren untuk spring dan fall tahun 2017 yang diterbitkan oleh Pantone, dengan palet warna yang dihasilkan adalah warna-warna yang lembut, muted, dan earthy dengan kombinasi warna dasar yang lebih mencolok (Pantone, 2016).

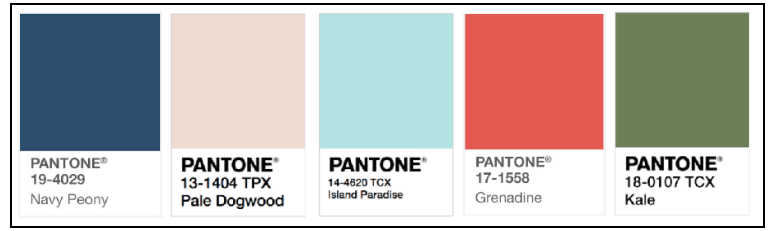

Gambar 13. Inspirasi Warna Tren Tahun 2017

Sumber: www.pantone.com

\section{PEMBAHASAN}

Pada bagian pembahasan adalah kelanjutan dari tahap pertama, yaitu tahap kedua yang berisi perancangan motif tekstil menggunakan teknik ilustrasi digital, kemudian dilanjutkan dengan fungsi penggunaan motif terhadap produk fashion.

\section{TAHAP KEDUA: HASIL PERANCANGAN MOTIF}

Menindaklanjuti hasil dari studi literatur serta observasi online dan offline, penulis merancang desain motif repetisi (repeat pattern) untuk tekstil yang menggambarkan 4 fauna dan 4 flora endemik Pulau Sumatra, disertai oleh unsur grafis dan gaya penyusunan motif yang terinspirasi dari motif batik Indramayu.

Teknik yang digunakan untuk perancangan motif adalah ilustrasi digital yang sepenuhnya dibuat menggunakan software Adobe Illustrator untuk memperoleh hasil motif tekstil dengan gaya desain yang kontemporer. 
Marini Yunita Tanzil

Penerapan Inspirasi Fauna dan Flora Sumatera Terhadap Perancangan Motif Tekstil Kontemporer

\section{ILUSTRASI FAUNA}

Dari tabel berikut adalah hasil dari ilustrasi digital dari fauna endemik Pulau Sumatra yang dipilih:

Tabel 1. Hasil ilustrasi digital fauna oleh Penulis

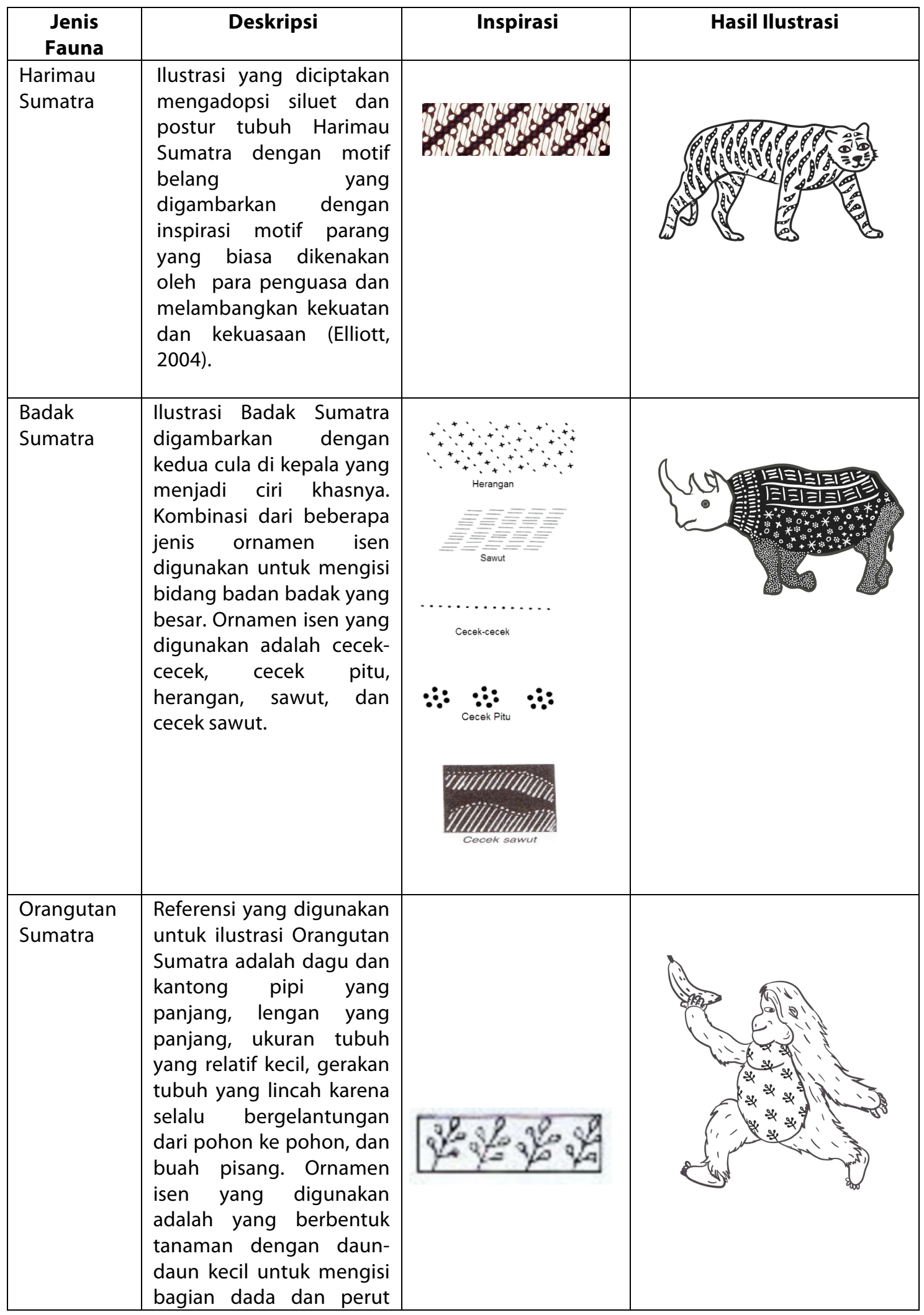




\begin{tabular}{|l|l|l|}
\hline & dari orangutan. & \\
\hline Burung & Burung Malayan Banded \\
Banded & Pitta yang digambar \\
adalah jenis kelamin & jantan yang memiliki \\
motif yang menyerupai \\
topeng hitam di matanya. \\
Ornamen yang digunakan \\
untuk mengisi sayap dan \\
tubuhnya diadaptasi dari \\
motif herangan.
\end{tabular}

\section{ILUSTRASI FLORA}

Ilustrasi untuk flora digambarkan dengan ornamen isen yang sederhana, seperti cecekcecek dan cecek sawut untuk menyeimbangkan ilustrasi fauna yang lebih kompleks. Dalam tabel berikut adalah hasil dari ilustrasi digital dari flora endemik Pulau Sumatra, serta tumbuh-tumbuhan seperti dedaunan dan sulur-sulur yang digunakan sebagai ornamen pelengkap:

Tabel 2. Hasil ilustrasi digital flora oleh Penulis

\begin{tabular}{|c|c|c|c|}
\hline Jenis Flora & Deskripsi & Inspirasi & Hasil Ilustrasi \\
\hline $\begin{array}{l}\text { Bunga } \\
\text { Suweg } \\
\text { raksasa }\end{array}$ & $\begin{array}{l}\text { Bunga Suweg raksasa yang } \\
\text { digambar adalah kondisi ketika } \\
\text { bunga sedang berada di fase } \\
\text { vegetatif, dengan daunnya } \\
\text { mekar dan batang tunggalnya } \\
\text { muncul dengan tegak (Fakta } \\
\text { Unik, 2017). Bagian dalam dari } \\
\text { daun diisi dengan ornamen } \\
\text { cecek-cecek. }\end{array}$ & & \\
\hline $\begin{array}{l}\text { Bunga } \\
\text { Rafflesia } \\
\text { arnoldii }\end{array}$ & $\begin{array}{l}\text { llustrasi bunga Rafflesia Arnoldii } \\
\text { digambarkan ketika sedang } \\
\text { mekar penuh dengan ornamen } \\
\text { cecek-cecek } \\
\text { menggambarkan tekstur pada } \\
\text { kelopak bunga. }\end{array}$ & & \\
\hline $\begin{array}{l}\text { Pinang } \\
\text { merah }\end{array}$ & $\begin{array}{l}\text { Unsur yang diambil adalah biji } \\
\text { dari pinang merah yang } \\
\text { memiliki bentuk yang khas } \\
\text { untuk merepresentasikan } \\
\text { tumbuhan tersebut. }\end{array}$ & & \\
\hline Dedaunan & Dedaunan dan sulur-sulur & & \\
\hline
\end{tabular}


Penerapan Inspirasi Fauna dan Flora Sumatera Terhadap Perancangan Motif Tekstil Kontemporer

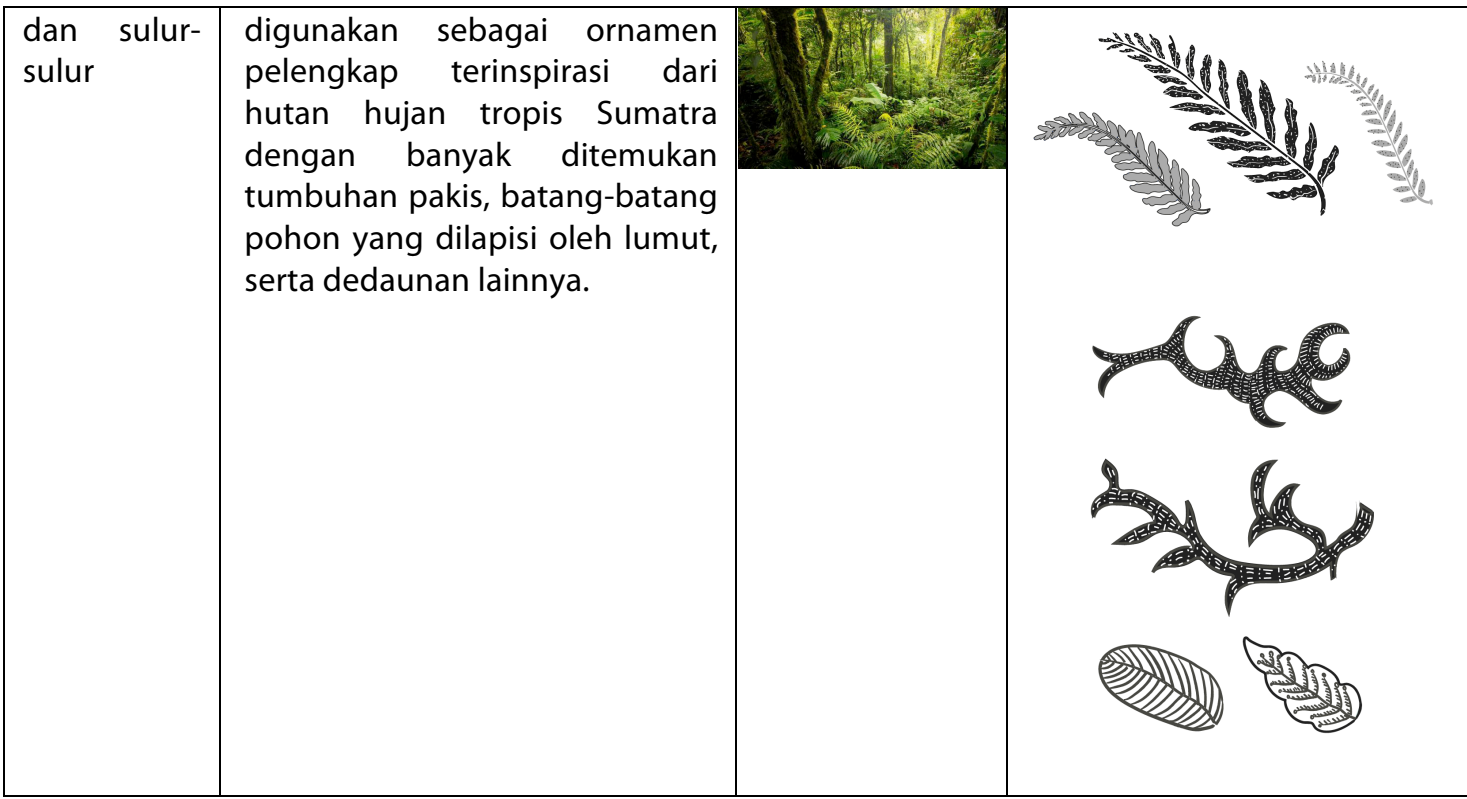

Sumber: koleksi pribadi

\section{HASIL PERANCANGAN MOTIF}

Ilustrasi hasil stilasi fauna dan flora dikomposisikan untuk membentuk motif untuk pattern repetisi dengan inspirasi motif batik Indramayu dan tren warna tahun 2017. Berikut adalah luaran dari perancangan motif dengan dua variasi komposisi warna:

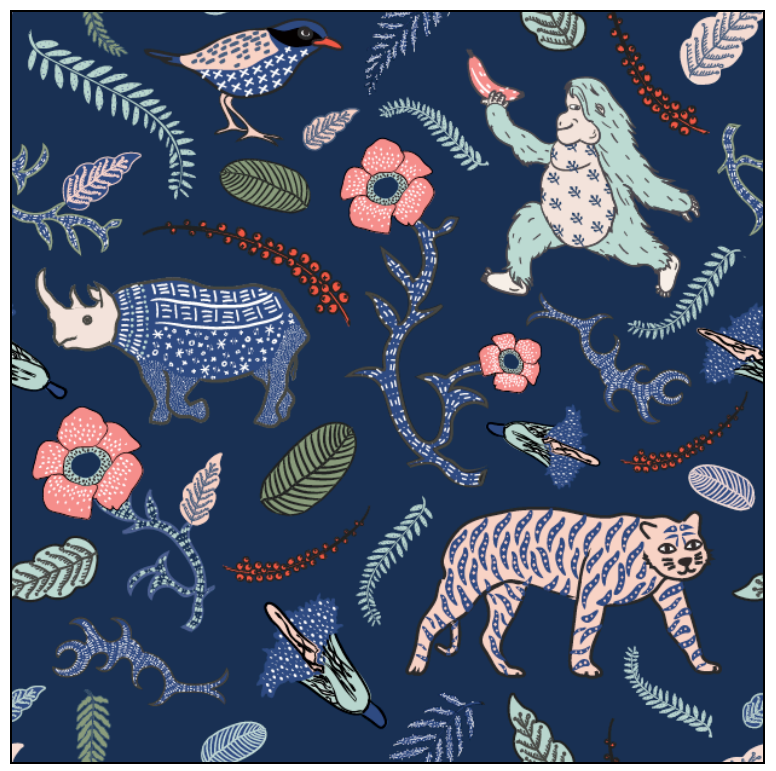

Gambar 14. Hasil Desain Motif Tekstil Alternatif 1 Sumber: koleksi pribadi 


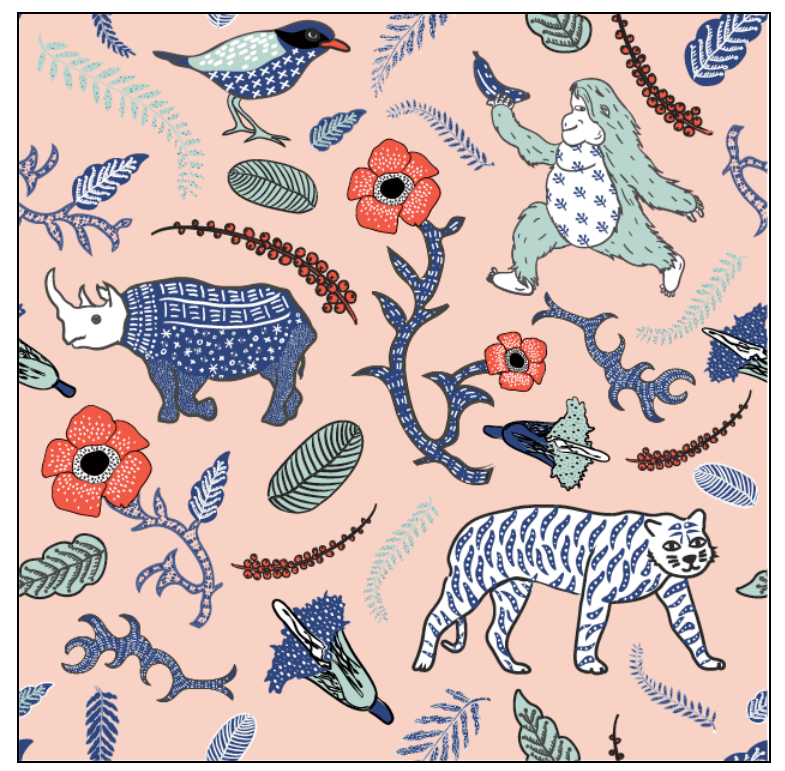

Gambar 15. Hasil Desain Motif Tekstil Alternatif 2 Sumber: koleksi pribadi

\section{APLIKASI MOTIF PADA PRODUK FASHION}

Hasil perancangan motif di atas direpetisi secara seamless menjadi pattern yang dapat diaplikasikan pada berbagai produk fashion. Berikut adalah contoh aplikasi motif pada scarf:

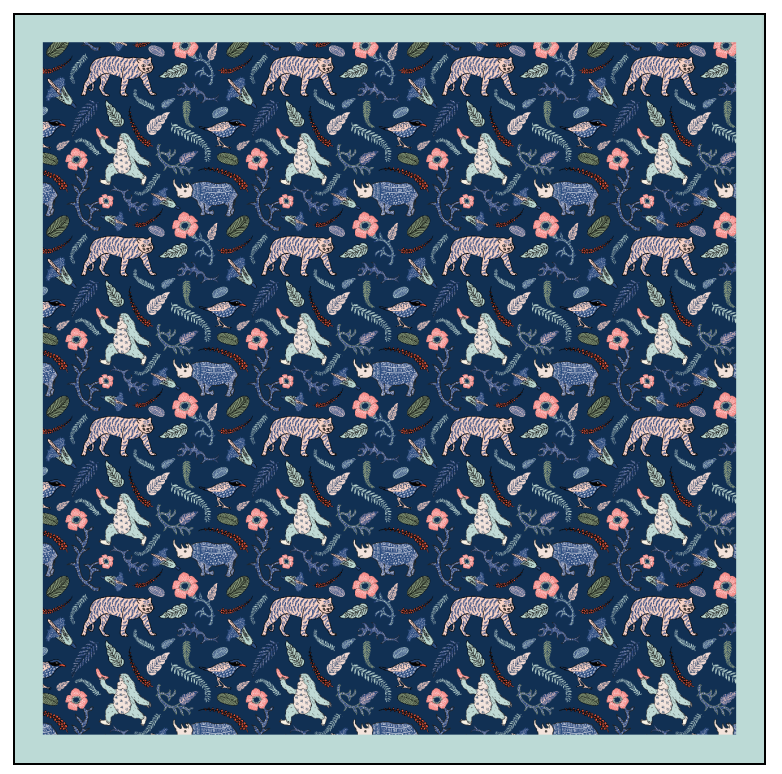

Gambar 16. Contoh Aplikasi Pattern Pada Scarf (alternatif 1) Sumber: koleksi pribadi 


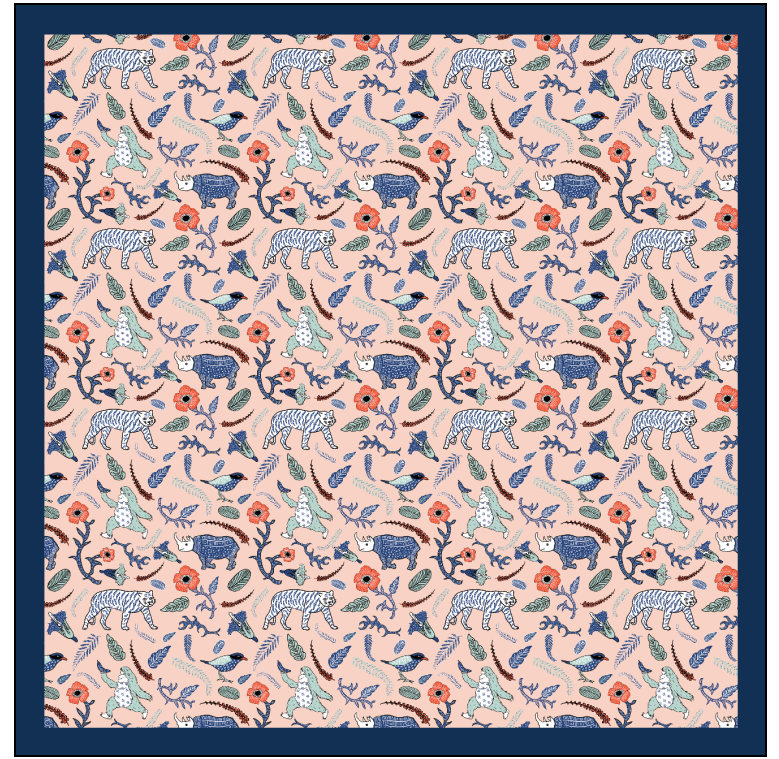

Gambar 17. Contoh Aplikasi Pattern Pada Scarf (alternatif 2) Sumber: koleksi pribadi

\section{PENUTUP}

Penelitian ini meninjau sumber alam hayati di Indonesia khususnya fauna dan flora endemik Pulau Sumatra yang merupakan kebanggaan negara Indonesia namun memiliki kondisi dan jumlah populasi yang memprihatinkan sebagai akibat dari penebangan dan pembakaran hutan, serta pemburuan liar yang tidak bertanggung jawab.

Berdasarkan hasil observasi, studi literatur, dan eksplorasi, dapat disimpulkan bahwa konten lokal yang terdiri dari unsur-unsur alam dan budaya dapat menjadi inspirasi untuk perancangan motif tekstil kontemporer dengan menggunakan gaya ilustrasi dan pemilihan warna terkini.

Melalui pattern sebagai media yang dapat menarik perhatian dan memicu emosi orang yang melihatnya, diharapkan motif tekstil dengan dari fauna dan flora Pulau Sumatra yang diaplikasikan pada produk fashion dapat meningkatkan ketertarikan dan kesadaran masyarakat baik lokal maupun internasional terhadap kekayaan hayati Indonesia dan risiko kepunahan yang sedang dihadapinya. 


\section{DAFTAR PUSTAKA}

Bowles, M. and Isaac, C. (2009). Digital Textile Design. London, UK: Laurence King Publishing. Clarke, C. (2011). Textile Design: Portfolio Series. London, UK: Laurence King Publishing.

Doe, T. (2015). Textile Design in The Digital Age: Textile Revolution. London, UK: Goodman Publishing.

Elliott, I. M. P. D. (2004). Batik: Fabled Cloth of Java (Periplus ed.). UK: Tuttle Publishing.

[Fakta Unik]. Lihat Baik-Baik! Proses Mekarnya Bunga Suweg Raksasa (Bunga Bangkai Raksasa). [Video File]. Diunduh pada 16 Maret 2017.

Fogg, M. (2006). Print in Fashion. London: Batsford

Gerhat. S. (2016). Palm Merah/Pinang Merah. Diunduh pada 8 April 2018.

Infobatik. (n.d.). Batik Indramayu Motif Lokcan. Diunduh pada 8 April 2018.

Justema, W. (1976). Pattern: A Historical Panorama. New York, US: HarperCollins Publishers L.L.C.

Kartasasmita, J. H. (2012). Dunia Batik Seorang Jultin. Indonesia: Red \& White Publishing.

Kawamura, Y. (2011). Doing Research in Fashion and Dress. Oxford, UK: Berg Publishers.

Kementerian Lingkungan Hidup dan Kehutanan. (2017). Statistik Lingkungan Hidup Dan Kehutanan Tahun 2016. Diunduh pada 4 April 2018.

O'Meara, K. and Keiffer, A. V. (2015). The Pattern Base: Over 550 Contemporary Textile and Surface Designs ( $1^{\text {st }}$ ed.). New Jersey, USA: Pearson Prentice Hall Publications.

Putri, G. S. (2018). Harimau Sumatera, Predator Buas yang Bantu Hutan Tetap Lestari. Diunduh pada 7 April 2018.

Ramos, J. (2016). Stolen Jewels: Protect Indonesia's 'Jewels of the Forest' from the Illegal Bird Trade Now. Diunduh pada 7 April 2018.

Ratya, M. P. (2017). Ini Data Terbaru Populasi Orangutan di Pulau Sumatera dan Borneo. Diunduh pada 7 April 2018.

Roojen, P.V. (2001). Batik Design. Amsterdam, The Netherlands: The Pepin Press.

Supriatna, J. (2008). Melestarikan alam Indonesia. Indonesia: Yayasan Obor Indonesia.

The Artist Editorial . (2017). The Difference Between Modern and Contemporary Art. Diunduh pada 8 April 2018.

WWF Indonesia . (n.d.). Bunga Bangkai (Amorphophallus). Diunduh pada 8 April 2018.

WWF Indonesia . (n.d.). Kehutanan. Diunduh pada 7 April 2018.

WWF Indonesia . (n.d.). Harimau Sumatera. Diunduh pada 7 April 2018. 